\title{
Stem Cell Culture Collection - Promising Strategy for Animal Genetic Resource Preservation
}

\author{
Weijun Guan, Xiangchen Li, Dapeng Jin, \\ Xiaohong He, Yabin Pu, Qianjun Zhao, Taofeng Lu, \\ Chunyu Bai, Shen $\mathrm{Wu}$, Xiaohua Su and Yuehui Ma \\ Institute of Animal Sciences, Chinese Academy of Agricultural Sciences, Beijing 100193 \\ PR China
}

\section{Introduction}

With the continuous increase of world population, intensified industrial activities, and aggravating environmental pollution, biodiversity is severely endangered to an unprecedented extent. Animal resources, a basis of agriculture and the whole society closely related to living and production, supply human beings with meat, eggs, milk, furs, medicinal materials, products for athletic and ornamental purposes, etc. In most developed countries, massive feeding is restricted within a limited number of high yield breeds or crossbreeds for an intensified operating system of animal husbandry, virtually reducing the variety of local animal breeds. In the meanwhile, despite the existence of enormous animal genetic resources, the lack of efficient preservation strategies and blind introduction of exotic breeds for hybridization have significantly compromised the diversity. As a result, only a few high-yield breeds and hybrids are made more widespread, and gradually supersede indigenous breeds, therefore leading to a shrunken genetic resource pool, progressive narrowing of genetic variation and subsequent crisis of genetic treasures. Nowadays, the livestock and poultry breeds are disappearing at the speed of 1 to 2 per week, so it's definitely far-reaching to explore an efficient and reasonable preservation method for the development of animal husbandry, utilization of animal resources and ecological balance.

As evolution has it, livestock and poultry breeds, the best narration of human labour, diet, religion and customs, is culturally a tangible carrier of civilization vicissitudes (Zhang, 2003). Those animal breeds with precious genome, physiological characteristics, disease resistance, adaptability, and so forth, serve as ideal research models. Moreover, the animal biodiversity provides abundant original materials for the thremmatologists, create infinite selection possibilities, reduce the risks and challenge of animal husbandry, and enhance its interior tenacity and exterior opportunities, thereby enabling people to handle environmental and marketing changes, and invigorating its long term development.

China has the most abundant genetic resources of livestock and poultry, featuring balanced breed range and characteristic distinction. Some genetic and phenotypic properties par excellence, such as adaptability, hardiness, fecundity, etc., are essentially the outcome of thousands-of-year interaction between natural environment and artificial breeding. 
According to the statistics from Food and Agriculture Organization (FAO), among the 3019 breeds of livestock and poultry all around the world, one third is located in Asia, of which china accounts for a half.

A survey of genetic resources and the assessment of "Chinese Committee of Livestock and Poultry Evaluation" in 2001 reported that the animal genetic resources of China involve chicken (Gallus gallus), duck (Anseriformes Anatidae), goose (Anser cygnoides orientalis), sandpiper (Scolopacidae), cattle (Bos taurus), sheep (Ovis aries), goat (Capra hircus), pig (Suidae), ferret-polecat (Mustela Pulourius Furot), raccoon dog (Nyctereutes procyonoides), horse (Equus caballus), red deer (Cerous elaphus), sika deer (Cerous nippon) bactrian camel (Camelus bactrianus), etc., which, altogether amount to some 20 species, 576 breeds (426 indigenous breeds, 73 fostered ones and 77 introduced ones) (Liu et al., 2004). However, in these years, the genetic resources are shrinking considerably due to the brunt of the massive introduction of high yield breeds. Data in the 70's and 80's suggested that within China, 10 indigenous breeds are disappearing, 8 are on the edge of extinction, and 20 are decreasing rapidly. Furthermore, a recent research suggested that more than $50 \%$ of local breed populations are extremely reduced, and that a large number of the rest are severely endangered (Ma et al., 2001).

In containing the huge loss of animal genetic resources, the preservation procedure has become a very concern of more and more researchers. The most important is to protect existential genetic materials from adulterating and extinction in a comprehensive and proper manner, which virtually means to preserve available genetic resources as integrated as possible, no matter whether there are application potentials from current perspective. For the preservation of population genome, there are optional forms, e.g. individuals, organs, semen, embryos, cell strains, genomic libraries, and cDNA libraries. It's noteworthy that the above-mentioned methods all have their defects, so appropriate strategies should be devised to fit in with specific species. A new preservation protocol using stem cells, is both novel and complementary to the existing multi-approach tactics, and thus will become a major technique in a long term. With the strenuous efforts scientists have ever made, preservation media of semen, embryos, cell strains, genomic libraries and natural reserves are primarily shaped. In contrast, preservation via stem cells is still lacking, which apparently has its distinguished advantages.

Stem cells can be categorized into embryonic stem cells (ESCs) and adult stem cells (ASCs) by origins. ESCs derived from inner cell mass have totipotency and continuous selfrenewal ability, and therefore are widely believed as the stem cells with the most therapeutic and research values. ASCs are ubiquitous in almost every organ of adult animals, to maintain the structural and functional homeostasis. The applications of ESCs in clinical therapies are open to doubt, mainly for ethnic reasons, propelling people to resort to the more applicable ASCs. Emerging evidence on the plasticity of ASCs and the presence of multipotent stem cells in adult tissues deepened the comprehension of their developmental repertoire.

For the preservation of animal genetic resources, stem cells, by virtue of their potent selfrenewal ability, can provide a large amount of serviceable cells with relatively small volume. Meanwhile, the plasticity of stem cells confers them more advantages in applications, for instance, in nuclear transfer. Stem cell cryopreservation is not only an efficient and safe strategy for the maintenance of animal genetic resources, but also promising to show scientific values in other fields of research.

This chapter will introduce the preservation of animal genetic resources in terms of animal cells and its applications by detailed experimental description. 


\section{Isolation, in vitro culture and identification of stem cell lines}

Preservation of animal genetic resources in terms of stem cells is essentially to store as many purified cells as possible, which impose strict criteria on the in vitro culture and identification of stem cells with various origins. Therefore, it plays a crucial role in the entire technical system to fulfil efficient and high quality culture and purification.

\subsection{In vitro culture}

\subsubsection{Sampling}

Stem cells are widely distributed in a variety of tissues and organs, thus it is of great importance to pinpoint and dissect the parts where the most stem cells populated. For instance, ESCs is located precisely in inner cell mass, while adult neural stem cells mainly reside in subventricular zone and hippocampal dentate gyrus. In addition, sterile operation and quick isolation are items of very concern as well, e.g. proper sterilization during sampling, hypothermal transportation, etc.

\subsubsection{Isolation}

Stem cells are unhomogenously distributed in vivo, which requires a lot to isolate as pure stem cells as possible using various available methods. Strategies for stem cell isolation of common types are as listed in Table 1 (except specially indicated otherwise, all the methods are primarily for avian species):

\subsubsection{In vitro cell culture}

Primary culture is the first step of cells into ex vivo environment. The time of this phase is contingent upon the adaptability of different stem cells, which, in turn, is just the basis for further purification. When primary cells grow to a certain density, leading to contact inhibition, along comes subculture process. During all this progress, most stem cells have got used to new circumstances, and go on rapid proliferation, reentering proliferation inhibition -proliferation cycles.

Because of the distinctive characteristics, each type of stem cells needs specific factors in its niche, e.g. epidermal growth factor (EGF), basic fibroblast growth factor (bFGF), glutamine, etc. In addition, feeder layer is necessary for successful culture of PGCs.

\subsubsection{Cryopreservation}

The purpose of in vitro stem cell culture is to conserve animal genetic resources, for which cyropreservation is optimal at cell level. Repetitive tests confirmed that cryonics of stem cells don't differ from those of somatic cells. However, for the preciousness of stem cells, serum concentration is elevated to an appropriate extent, which is to say, the cryogenic media are composed of $50 \%$ basic media, $40 \%$ serum and $10 \%$ cryoprotectant (DMSO), fundamentally capable of ensuring the viability of resuscitated cells.

\subsection{Identification}

Stem cells preserved as genetic resources should be subjected to evaluation of at least two major respects. One is assessment of general biological characteristics. The other is about stem cell properties in terms of specific markers, self renewal and plasticity. 


\begin{tabular}{|c|c|c|}
\hline Cell type & $\begin{array}{l}\text { Isolation } \\
\text { methods }\end{array}$ & Protocols \\
\hline \multirow{2}{*}{$\begin{array}{l}\text { Bone marrow } \\
\text { mesenchymal } \\
\text { stem cells } \\
\text { (MSCs) }\end{array}$} & $\begin{array}{l}\text { Total blood } \\
\text { adherent } \\
\text { method }\end{array}$ & $\begin{array}{l}\text { Bone marrow was suspended into } 10 \mathrm{ml} \text { serum-free L-DMEM } \\
\text { medium containing } 100 \mathrm{IU} / \mathrm{ml} \text { penicillin and } 100 \mu \mathrm{g} / \mathrm{ml} \\
\text { streptomycin using syringe, and then was pipetted into cell } \\
\text { suspension with } 4 \# \text { needle gently. The cell suspension was } \\
\text { centrifuged at } 1000 \mathrm{rpm} \text { for } 10 \mathrm{~min} \text {, the top fat impurities were } \\
\text { removed. The bottom cells were harvested and washed twice } \\
\text { using serum-free L-DMEM medium, resuspended with } \\
\text { complete medium, and subsequently plated into a culture } \\
\text { flask with } 10 \mathrm{ml} \text { complete medium. }\end{array}$ \\
\hline & $\begin{array}{l}\text { Density } \\
\text { gradient } \\
\text { centrifugation } \\
\text { method }\end{array}$ & $\begin{array}{l}\text { Bone marrow single cell suspension was prepared as above, } \\
\text { and gently added into a } 10 \mathrm{ml} \text { centrifuge tube with } \\
\text { isovolumic, } 1.073 \mathrm{~g} / \mathrm{ml} \text { percoll solution underneath. Then the } \\
\text { nebulous white ring on the interface of percoll and cell } \\
\text { suspension was pipetted out and washed twice using L- } \\
\text { DMEM and centrifuged for } 5 \mathrm{~min} \text { at } 1000 \mathrm{rpm} \text {. After } \\
\text { counting, these cells were plated into flasks at } 2 \times 10^{5} / \mathrm{cm}^{2} \text {, } \\
\text { and cultured at } 37^{\circ} \mathrm{C}, 5 \% \mathrm{CO}_{2} \text {. }\end{array}$ \\
\hline $\begin{array}{l}\text { Primordial } \\
\text { germ cells } \\
\text { (PGCs) }\end{array}$ & $\begin{array}{l}\text { Trypsinization } \\
\text { method }\end{array}$ & $\begin{array}{l}\text { PGCs were retrieved from the embryonic gonads incubated at } \\
38{ }^{\circ} \mathrm{C} \text { and } 60 \% \text { humidity for } 5.5 \text { days. After rinsing } 3 \text { times } \\
\text { with PBS to remove residual yolk, gonadal tissues were } \\
\text { collected carefully with sharp tweezers under a microsurgery } \\
\text { microscope, and then dissociated in } 0.25 \% \text { trypsin- } 0.02 \% \\
\text { EDTA at room temperature (RT) for } 5 \text { min. After inactivation } \\
\text { of the trypsin-EDTA with DMEM containing } 15 \% \text { FBS, the } \\
\text { cells were harvested by centrifugation (Zhang, 2003). These } \\
\text { cells were plated into flasks at } 2 \times 10^{5} / \mathrm{cm}^{2} \text {, and cultured at } \\
37^{\circ} \mathrm{C}, 5 \% \mathrm{CO}_{2} \text {. }\end{array}$ \\
\hline $\begin{array}{l}\text { Adipose } \\
\text { derived stem } \\
\text { cells (ADSCs) }\end{array}$ & $\begin{array}{l}\text { Collagenase } \\
\text { method }\end{array}$ & 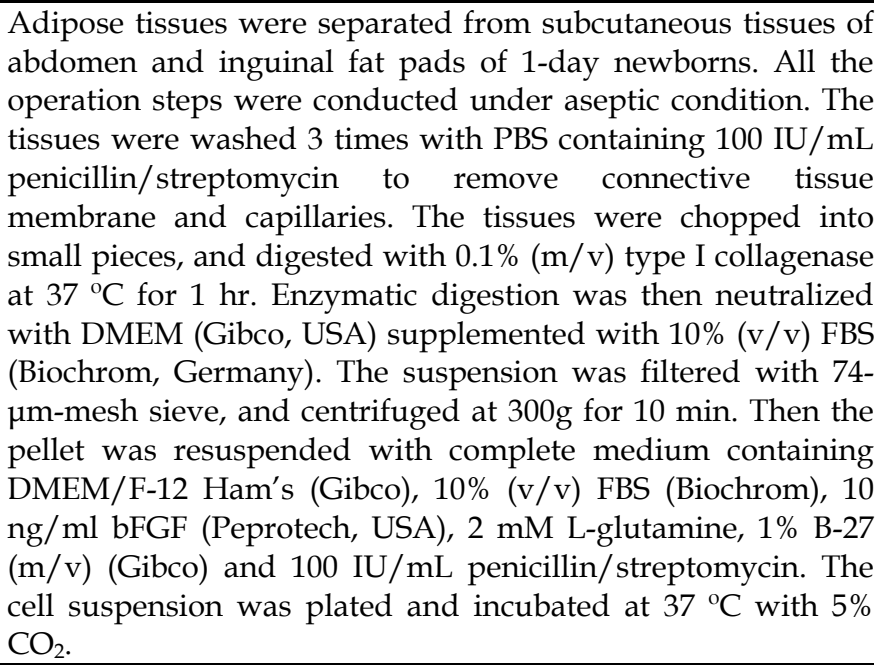 \\
\hline
\end{tabular}




\begin{tabular}{|c|c|c|}
\hline Cell type & $\begin{array}{l}\text { Isolation } \\
\text { methods }\end{array}$ & Protocols \\
\hline $\begin{array}{l}\text { Skeletal } \\
\text { muscle } \\
\text { satellite cells } \\
\text { (SCs) }\end{array}$ & $\begin{array}{l}\text { Collagenase } \\
\text { method }\end{array}$ & $\begin{array}{l}\text { Skeletal muscles were isolated from embryos and chopped } \\
\text { into pieces using ophthalmic scissors. The comminuted tissues } \\
\text { were disaggregated by combinatorial digestion with } 0.1 \% \\
\text { collagenase I for } 30 \mathrm{~min} \text { and } 0.25 \% \text { trypsin for } 1 \mathrm{~h} \text {. Then add } \\
\text { DMEM medium containing } 20 \% \mathrm{FBS} \text { to terminate reaction. } \\
\text { The cell suspension was centrifuged at } 1,500 \mathrm{rpm} \text { for } 8 \mathrm{~min} \\
\text { with the supernatant discarded, whereafter the cells were } \\
\text { resuspended with complete medium(DMEM/F12 }+20 \% \text { FBS+ } \\
2.5 \mathrm{ng} / \mathrm{ml} \text { bFGF) and plated into flasks. Cells were cultured in } \\
5 \% \mathrm{CO}_{2} \text { incubator at } 37{ }^{\circ} \mathrm{C} \text { for } 2 \mathrm{~h} \text {, and then plate the cell } \\
\text { suspension to petri dishes, to continue culturing at } 37^{\circ} \mathrm{C} \text {, in } \\
5 \% \mathrm{CO}_{2}(\mathrm{Qu} \text { et al., 1998). }\end{array}$ \\
\hline $\begin{array}{l}\text { Neural stem } \\
\text { cells (NSCs) }\end{array}$ & $\begin{array}{l}\text { Mechanical } \\
\text { isolation }\end{array}$ & $\begin{array}{l}\text { Embryonic brains were isolated and rinsed } 3 \text { times and then } \\
\text { placed in precooled normal saline water. The dorsal } \\
\text { ventricular ridges of the brain were isolated, rinsed, and } \\
\text { transferred to complete neural stem cell media } 1: 1 \\
\text { DMEM/F12 (Gibco, Carlsbad, CA), } 2 \% \text { B27 supplement } \\
\text { (Gibco), } 20 \mathrm{ng} / \mathrm{mL} \text { of EGF and bFGF (PeproTech, Rocky Hill, } \\
\mathrm{NJ}), 100 \mathrm{IU} / \mathrm{ml} \text { penicillin/streptomycin, cleaved into } 1.0 \mathrm{~mm}^{3} \\
\text { pieces, and pipetted repeatedly to prepare a homogeneous } \\
\text { monoblast suspension, which was subsequently filtered } \\
\text { through } 400 \text { - and } 800 \text {-mesh sieves in order. The entire } \\
\text { operation was performed under a low temperature to protect } \\
\text { the cortex tissues. The cells were plated in flasks at a } \\
\text { concentration of } 2 \times 10^{5} \text { cells } / \mathrm{mL} \text { and were cultured in a } \\
\text { humidified incubator with } 5 \% \mathrm{CO}_{2} \text { at } 37^{\circ} \mathrm{C} \text {. }\end{array}$ \\
\hline
\end{tabular}

Table 1. Isolation methods of several types of stem cells

General biological characteristics include hereditary stability (karyotyping), growth dynamics (growth curve), microbial detection, cross-contamination detection, viabilty before and after cryopreservation and the expression of exogenous genes. As for stem cell nature, specific markers are detected via immunofluorescence and immunochemistry, RT-PCR assay, Western blotting, etc. Self-renewal is evaluated using clonogenic assay. To verify the plasticity, the stem cells are induced for multi-lineage differentiation, which are then identified functionally. The fundamental principles will be introduced in detail in the following paragraphs.

\subsubsection{Growth dynamics}

Following Bai's method (2010), the stem cells were plated in 24-well plates at a concentration of $1 \times 10^{4}$ cells/well and cultured for 9 days (Bai et al., 2010). The cell concentration was counted using hematometer and then recorded from 3 wells per day until the plateau phase was reached. The growth curve was plotted and the population doubling time (PDT) was calculated accordingly. The formula is as follows:

$$
\mathrm{PDT}=\left(\mathrm{t}-\mathrm{t}_{0}\right) \lg 2 /\left(\lg \mathrm{N}_{\mathrm{t}}-\lg \mathrm{N}_{0}\right)
$$


$t_{0}$ : the initiating time of culture; $t$ : the end time of culture; $N_{0}$ : the cell numbers of initiating culture; $\mathrm{N}_{\mathrm{t}}$ : the cell number of end culture.

\subsubsection{Microbial detection}

\section{Detection of bacteria and fungi:}

The cells were cultured in DMEM containing 10\% fetal bovine serum without antibiotics and tested for the presence of microbes 3 days after subculture according to the method of Doyle et al. (1990).

\section{Mycoplasma detection:}

The cells were cultured in medium free of antibiotics for at least one week and then fixed and stained with Hoechst 33258 according to Masover (1998) and Freshney's method (2000). Results of DNA staining were confirmed by ELISA using the ELISA Mycoplasma Detection kit (Roche, Lewes, East Sussex, UK.), which can identify the four most common Mycoplasma species: M .arginini, M. hyorhinis, A .laidlawii, and M. orale.

\section{Virus detection:}

Routine examination for cytopathogenic effects using phase-contrast microscopy was performed according to Hay's haemadsorption protocol (Hay, 1992).

\subsubsection{Cryopreservation and resuscitation}

Cells were cultured in fresh medium $24 \mathrm{~h}$ prior to cryopreservation to ensure sufficient nutrition and optimal cellular condition. The monoplast suspension was prepared by dissociating cells in $0.25 \%(\mathrm{~m} / \mathrm{v})$ Trypsin. The suspension was centrifuged at $1000 \mathrm{rpm}$ for 8 min and the supernatant was discarded. Then, the cells were resuspended at a density of approximately $4 \times 10^{6} / \mathrm{mL}$ in freezing media of $10 \%$ dimethyl sulfoxide (DMSO), $40 \%$ FBS and $50 \%$ DMEM, and then subpackaged in cryovials which labeled the species, breeding, gender, date and serial numbers. The vials were placed at $4^{\circ} \mathrm{C}$ for $20-30 \mathrm{~min}$ to enable the DMSO to reach equilibrium, and then placed in liquid nitrogen for long term storage (Ren et al., 2002). For resuscitation, they were placed in prewarmed water bath at $42{ }^{\circ} \mathrm{C}$. As soon as it was nearly thawed, the pellet and suspension were transferred into a sterile tube containing DMEM and centrifuged at $1000 \mathrm{rpm}$ for $10 \mathrm{~min}$ to remove DMSO. The cells were then resuspended in fresh DMEM and plated onto petri dishes, and cultured in $5 \% \mathrm{CO}_{2}$, $37^{\circ} \mathrm{C}$. Medium should be refreshed after $24 \mathrm{~h}$ (Ren et al., 2002; Freshney, 2000).

\subsubsection{Karyotyping}

Metaphase spreads were prepared from cells at exponential phase following treatment with $0.1 \mu \mathrm{g} / \mathrm{mL}$ colcemid (Gibco/BRL). The cells were treated with a hypotonic solution (KCl/HEPES/EDTA) and harvested according to standard dissociation procedures. Slides of fixed cells were Giemsa banded to identify individual metaphase chromosomes. Representative chromosome sets were photographed and analyzed. The percent of diploid was counted from 100 cells. Karyotypes were processed following the protocol described in the Reading Conference report (Ford et al., 1980).

These chromosomal parameters were calculated using the formulas:

$$
\text { Arm ratio }=\text { long arm length }(q) \text { vs short arm length }(p)
$$


Centromere index =short arm length vs chromosomal length

Relative length=single chromosomal length vs (total autosome lengths $+\mathrm{X}$-chromosome length)

\subsubsection{Expression of exogenous genes}

According to the method described by Tsuchiya et al. (2002), the same quantity of the fluorescent protein vectors $\mathrm{pEGFP-N3}$, pDsRed-N1 and pEYFP-N1 were transfected into the stem cells with Lipofectamine ${ }^{\mathrm{TM}} 2000$ transfection reagent (Invitrogen Corp, Carlsbad, CA). The plasmid DNA $(\mu \mathrm{g})$ to Lipofectamine $2000(\mu \mathrm{l})$ ratio was 1:3. After $8 \mathrm{~h}$, the cells were removed from non-serum medium and transferred to serum containing medium. Cell morphology was observed, and the cells were dyed with Trypan Blue to estimate the viability. The cells were observed after being transfected for $24 \mathrm{~h}, 48 \mathrm{~h}$ and $72 \mathrm{~h}$, respectively, to estimate the transfection efficiency. Cell morphology was observed by confocal microscopy (Nikon TE-2000-E, Japan), and a comparative analysis of expression was made according to the intensity of the different fluorescent proteins in the cell nuclei and cytoplasm. For each individual experiment, images were captured from 10 visual fields, and confocal microscopy was used to measure the total and positive cell counts in each field to determine the transfection efficiency. The mean values were accordingly calculated. Multiple comparisons of the test data were made to analyze the statistical differences (Tsuchiya et al., 2002).

\subsubsection{Identification of characteristic markers}

Stem cells with various origins possess different markers, providing a major approach to identify their lineages (Table 2). Prior to cryopreservation, it is extremely necessary to find molecular evidence for their identity. These markers are generally detected by three commonly used assays, i.e. immunofluorescence, immunochemistry and RT-PCR.

\begin{tabular}{cc}
\hline Cell types & Markers \\
\hline BMSCs & CD44, ICAM-1, SSEA-4 \\
PGCs & SSEA-1, SSEA-4, TRA-1-60, TRA-1-81 \\
ADSCs & CD29, CD44, CD71, CD73 \\
SMSCs & Pax7, Desmin, Myod \\
nscs & Nestin \\
\hline
\end{tabular}

Table 2. Characteristic markers of some kinds of stem cells

\section{Immunofluorescence}

Surface markers of different passages of the stem cells were detected by immunofluorescence. Stem cells were fixed in $4 \%(\mathrm{~m} / \mathrm{v})$ paraformaldehyde (in PBS) for 15$20 \mathrm{~min}$, and then permeabilized for $20 \mathrm{~min}$ with methanol containing $0.1 \%$ Triton $\mathrm{X}-100$ and $0.3 \%$ hydrogen peroxide $\left(\mathrm{H}_{2} \mathrm{O}_{2}\right)$ to eliminate endogenetic hydrogen peroxidise. Incubated in goat serum working solution for $30 \mathrm{~min}$ to block nonspecific binding, the cells were then incubated with primary antibodies at $4{ }^{\circ} \mathrm{C}$ overnight, followed by incubation with secondary antibodies conjugated with FITC. For negative control, $0.01 \mathrm{~mol} / \mathrm{L}$ PBS was used to replace primary antibodies. Fluorescence images were observed using confocal microscope (Nikon TE-2000-E, Japan). Ten non-overlapped visual fields $(\times 100)$ were photographed randomly 
from stem cells of different passages, then the percentage of positive cells to total count of stem cells was calculated and the results were formulated as mean $\pm \mathrm{SD}$, and subjected to variance analysis using SPSS 10.0 software.

\begin{tabular}{|c|c|c|c|c|}
\hline Genes & Primer Sequences & $\begin{array}{l}\text { Tm } \\
\left({ }^{\circ} \mathrm{C}\right)\end{array}$ & $\begin{array}{l}\text { Cycle } \\
\text { No. }\end{array}$ & Size (bp) \\
\hline CD29 & $\begin{array}{l}\text { F 5' GAACGGACAGATATGCAACGG 3' } \\
\text { R 5' TAGAACCAGCAGTCACCAACG 3' }\end{array}$ & 60 & 30 & 300 \\
\hline CD44 & $\begin{array}{c}\text { F 5' CATCGTTGCTGCCCTCCT 3' } \\
\text { R 5' ACCGCTACACTCCACTCTTCAT 3' }\end{array}$ & 58 & 30 & 290 \\
\hline CD71 & $\begin{array}{c}\text { F 5' CCCAGGCTTCCCTTCGT 3' } \\
\text { R 5' GGGCTCCAATCACAACATAC 3' }\end{array}$ & 56 & 30 & 305 \\
\hline CD73 & $\begin{array}{l}\text { F 5' AGTGCAAACATTAAGGGAAAA 3' } \\
\text { R 5' CCTCCAATAACAACATCCACTCCT } 3^{\prime}\end{array}$ & 58 & 30 & 310 \\
\hline Collage type I & $\begin{array}{l}\text { F 5' AAGGATGGTCGCAATG 3' } \\
\text { R 5' GGTGGCTAAGTCTGAGGT 3' }\end{array}$ & 48.5 & 30 & 310 \\
\hline Osteopontin & $\begin{array}{l}\text { F 5' CAGAACAGCCGGACTTTC 3' } \\
\text { R 5' CTTGCTCGCCTTCACCAC 3' }\end{array}$ & 51 & 30 & 227 \\
\hline PPARY & $\begin{array}{l}\text { F 5' CTGTCTGCGATGGATGAT 3' } \\
\text { R 5' AATAGGGAGGAGAAGGAG 3' }\end{array}$ & 47.3 & 30 & 199 \\
\hline $\begin{array}{l}\text { Lipoproteinlipase } \\
\text { (LPL) }\end{array}$ & $\begin{array}{l}\text { F 5' AGTGAAGTCAGGCGAAAC 3' } \\
\text { R 5' ACAAGGCACCACGATT 3' }\end{array}$ & 48.7 & 30 & 477 \\
\hline Desmin & $\begin{array}{l}\text { F 5' GGGCTTTCTCCTACCTGC 3' } \\
\text { R 5' GCTTCCTTGCCATCCTGT 3' }\end{array}$ & 57 & 30 & 240 \\
\hline MyoD1 & $\begin{array}{l}\text { F 5' GCTACTACACGGAATCACCA 3' } \\
\text { R 5' GGGCTCCACTGTCACTCA 3' }\end{array}$ & 57 & 30 & 198 \\
\hline GAPDH & $\begin{array}{l}\text { F 5' TAAAGGCGAGATGGTGAAAG 3' } \\
\text { R 5' ACGCTCCTGGAAGATAGTGAT 3' }\end{array}$ & 53 & 30 & 244 \\
\hline
\end{tabular}

Table 3. Primers for RT-PCR assay

\section{RT-PCR assay}

RNA was extracted from cells of different passages using Trizol reagent (Invitrogen, USA). Template cDNA was prepared with reverse transcription system (Takara, China) and then amplified by PCR using specific primers listed in Table 3. The PCR products were visualized by $2 \%(\mathrm{~m} / \mathrm{v})$ agarose gel electrophoresis.

\subsubsection{Clonogenic assay}

Stem cells of different passages were plated in 24-well microplates at the density of $1 \times 10^{4}$ cells per well, cultured for $7 \mathrm{~d}$, and then counted for the numbers of colony-forming units (CFU) to calculate colony-forming rate, which is formulated as CFU number/ plating cell number $\times 100 \%$.

\subsubsection{Induced differentiation and identification}

\section{Induced differentiation}

Stem cells are characterized by the potentials to escape cell cycle and to differentiate into terminal cells upon exposure to inducing media. Therefore, their plasticity is one important aspect which is a constitutional factor to evaluate for the sake of genetic preservation. 


\section{Osteogenic differentiation}

The stem cells of $80 \%$ confluence were divided into two groups. The induction group was incubated in osteogenic media ( $\beta$-sodium glycerophosphate, dexamethasone, vitamin $C$ ) containing osteoblasts. The control group were incubated in the same inducing medium without osteoblasts. Culture medium was changed every 3 days. Two weeks later, alkaline phosphatase levels were measured by the Gomori Ca-Co method. Three weeks later, Alizarin Red staining was used to detect calcium nodules. Four weeks later, Von Kossa's method and tetracycline fluorescence labeling of calcium were used to determine calcium nodules (Li et al., 2009).

\section{Adipogenic differentiation}

Stem cells were plated and divided into 2 groups as above mentioned. When the cells grew to $50 \%-60 \%$ confluence, the induced group was incubated in adipogenic medium supplemented with dexamethasone (Sigma), isobutyl-methylxanthine (IBMX; Sigma), and insulin (Sigma), while the control group was still cultured in complete medium. After 3 weeks, the two groups were stained with Oil Red $O$ to assess intracellular lipid accumulation. The RNA from the two groups was extracted for further RT-PCR assay.

\section{Neurogenic differentiation}

The preparation of stem cells was the same as above mentioned. Stem cells in the induction group were induced with medium containing $20 \%$ fetal bovine serum and $\beta$ mercaptoethanol (BME, Sigma, USA) for $24 \mathrm{~h}$, washed thrice with PBS, and then induced with serum-free medium containing dimethyl sulphoxide (DMSO, Sigma) and butylated hydroxyanisole (BHA, Sigma). Stem cells in the control group were incubated with normal culture medium. The neurogenic differentiation was then detected using immunofluorescence and observed under confocal microscope (Nikon TE-2000-E, Japan). Ten non-overlapped visual fields $(\times 100)$ were randomized from induced cells, followed by the same data processing as previously mentioned.

\section{Cardiomyogenic differentiation}

Cells were plated and divided into 2 groups as above mentioned. The induced group was incubated in serum-free cardiomyogenic medium containing 5-Azacytidine (5-aza; Sigma) for $24 \mathrm{~h}$, and then the medium was replaced with normal culture medium. After 28 days, the cells were harvested and the RNA from the two groups was extracted for further RT-PCR assays.

\subsection{Case study}

The Animal Population Culture Collection of China (APCCC) has been making efforts to preserve animal genetic resources in terms of stem cells, which involve bone marrow mesenchymal stem cells (MSCs), primordial germ cells (PGCs), adipose derived stem cells (ADSCs), skeletal muscle satellite cells (SCs), neural stem cells (NSCs), etc. Now they will be exemplified one by one.

\subsubsection{Evaluation of general biological indices}

The stem cells with different origins display fusiform or round shapes and swirl-like or sphere-like patterns, and most of them have plump cytoplasm, one of the indications of good vitality (Fig. 1). 
The growth curve of stem cells typically display typical "S" shapes, which are composed of latency phase, exponential growth phase and stationary phase, based on which PDT is calculated as a reflection of proliferative activity (Fig. 2). It's also worth mentioning that there are slight differences among different passages.

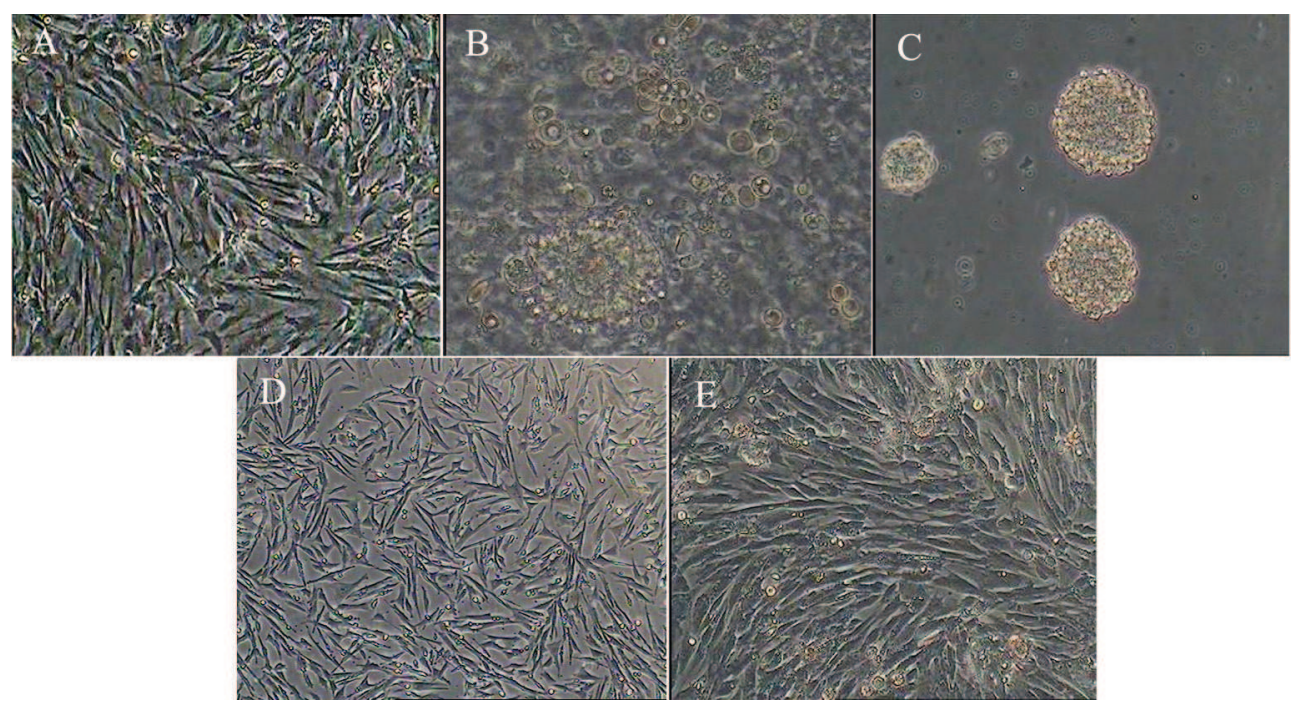

Fig. 1. Morphology of (A) duck bone marrow MSCs; (B) chicken PGCs; (C) duck NSPCs; (D) chicken ADSCs; (E) chicken skeletal muscle SCs.
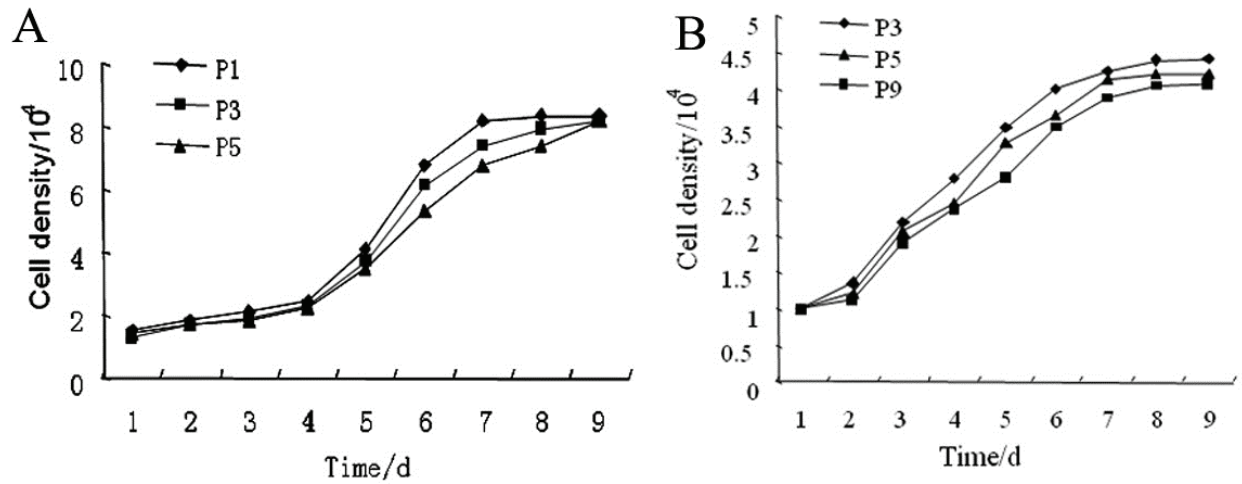

Fig. 2. Growth curves of (A) duck bone marrow MSCs of passages 1, 3 and 5; and (B) chicken ADSCs of passages 3,5 and 9. The growth curve of the different passages of duck MSCs and chicken ADSCs display typical " $S$ " shapes, which are composed of latency phase, exponential growth phase and stationary phase. 
In a sharp contrast with infections by bacteria, fungi and yeasts (Fig. 3 B, C and D), characterized by turbidity, colony or hypha which can be observed by unaided eyes, the mycoplasma contamination (Fig. $3 \mathrm{~F}$ ), usually undistinguishable, is only accompanied with slightly slower growth and increased cell fragmentation. As a result, Hoechst 33258 staining or molecular assays are required further. Therefore, all the stem cells are subjected to microbial detection prior to cryopreservation to ensure they are free of contamination (Fig.3 $\mathrm{A}$ and $\mathrm{E})$.

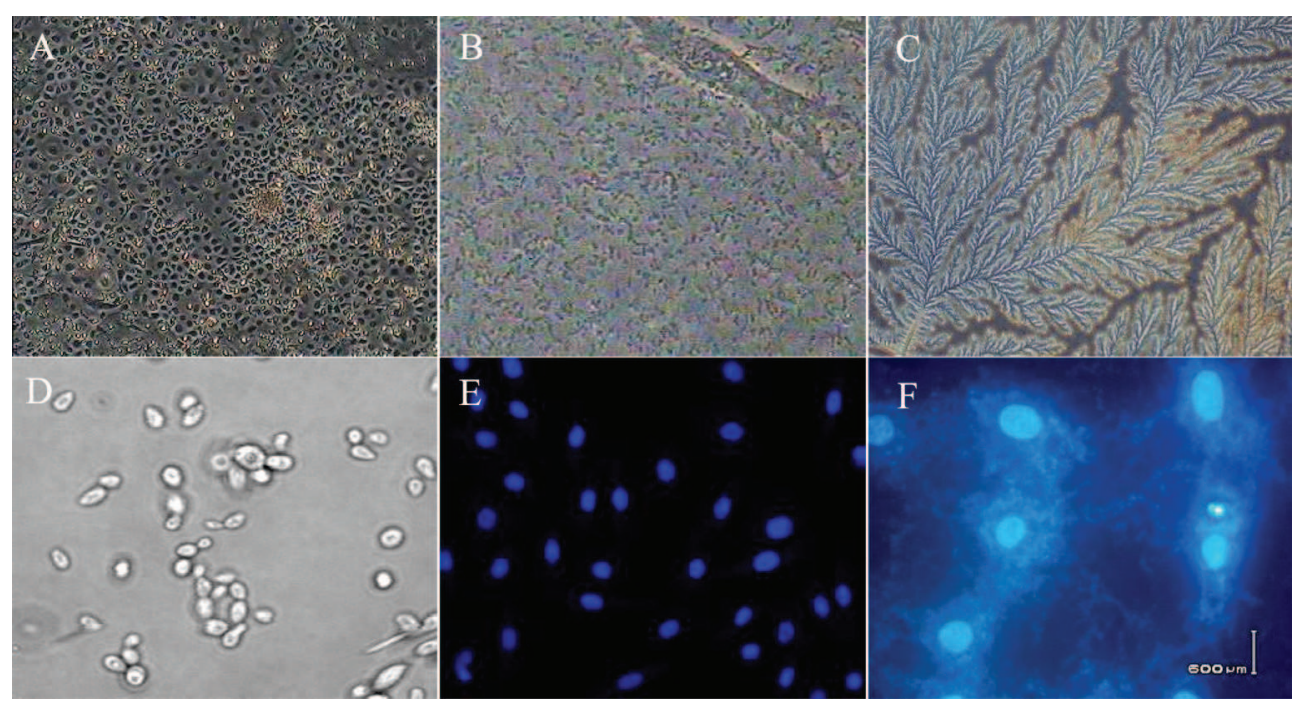

Fig. 3. Microbial detection of duck bone marrow MSCs. (A) normal bone marrow MSCs (40×); positive control infected by (B) bacteria (200×) and (C) fungi (200×); and (D) yeasts (200x); (E) bone marrow MSCs, mycoplasma negative (200x); (F)positive control infected by mycoplasma (400×). 
Cells possess a characteristic chromosome number, shape and structure, which remain very stable in normal cells (Fig. 4). Therefore, karyotype analysis is a major method for distinguishing normal cells from mutants. The percentage of diploid cells tends to decrease with increasing passage number. However, the fact that the diploid proportion is normally higher than $90 \%$ warrants the hereditary stability.

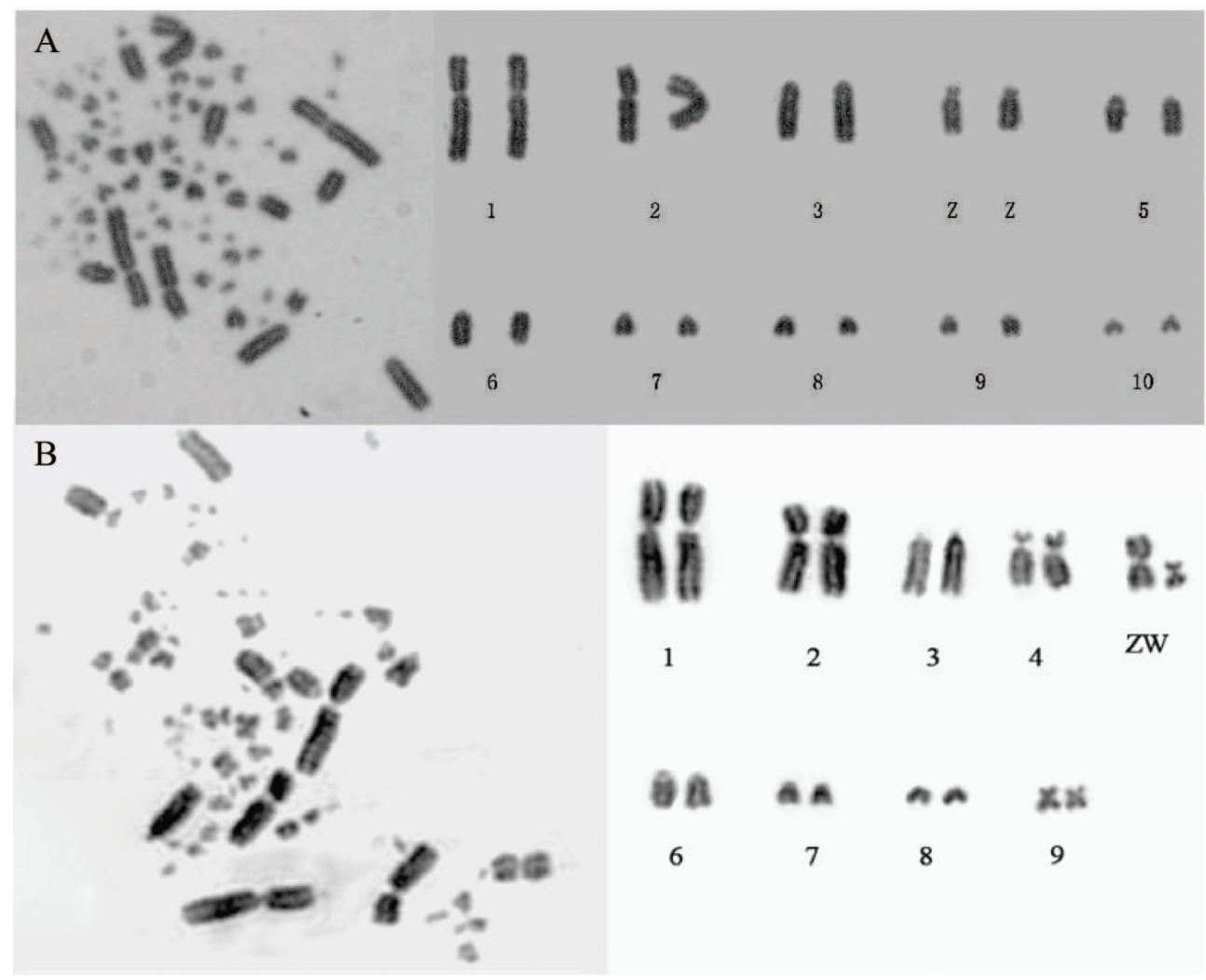

Fig. 4 Representative spreads at metaphase (left) and karyotypes (right) of (A) duck bone marrow MSCs, ZZ type ( $\left.0^{7}\right)$; (B) chicken PGCs, ZW type (우). The chromosomal number of duck bone marrow MSCs is 78, consisting of 10 pairs of macrochromosomes and 29 pairs of microchromosomes, while that of chicken PGCs $(2 n=78)$ is composed of 9 pairs of macrochromosomes and about 30 pairs of microchromosomes. 
Fluorescent genes, in light of their stable expression and species-independent efficiency, have long been used as markers to monitor the function and distribution target proteins in live cells and organisms (Heim, 1995). The expression levels of EGFP, EYFP, and DsRed1 are usually maximal at $48 \mathrm{~h}$ (Fig. 5). In addition, different fluorescent protein genes may have different transfection efficiency for the same cell line. As for most types of stem cells preserved, the transfection efficiencies of the yellow (pEYFP-N1) and red (pDsRed1-N1) fluorescent protein genes are significantly lower than those of the green fluorescent protein gene (pEGFP-N3).

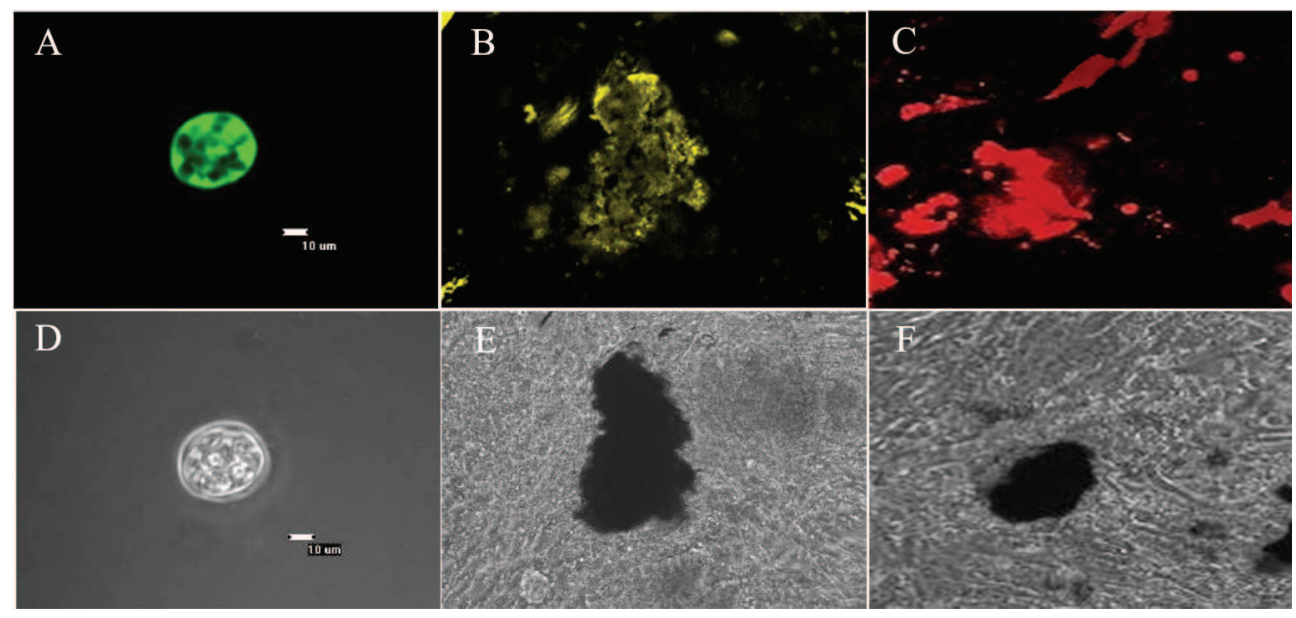

Fig. 5. The expression of (A, D) pEGFP-N3; (B, E) pEYFP-N1; and (C, F) pDsRed-N1 at $48 \mathrm{~h}$ in chicken PGCs. The expression of the three types of exogenous fluorescent genes is optimal at $48 \mathrm{~h}$, and the transfected cells exhibit no obvious difference in morphology and proliferation compared with controls. The pEGFP-N3, pEYFP-N1, and pDsRed-N1 refer to plasmids encoding the green, yellow and red fluorescent genes, respectively. Scale bars: 10 $\mu \mathrm{m}$ in $\mathrm{A}$ and $\mathrm{D}, 80 \mu \mathrm{m}$ in $\mathrm{B}, \mathrm{C}, \mathrm{E}$ and $\mathrm{F}$.

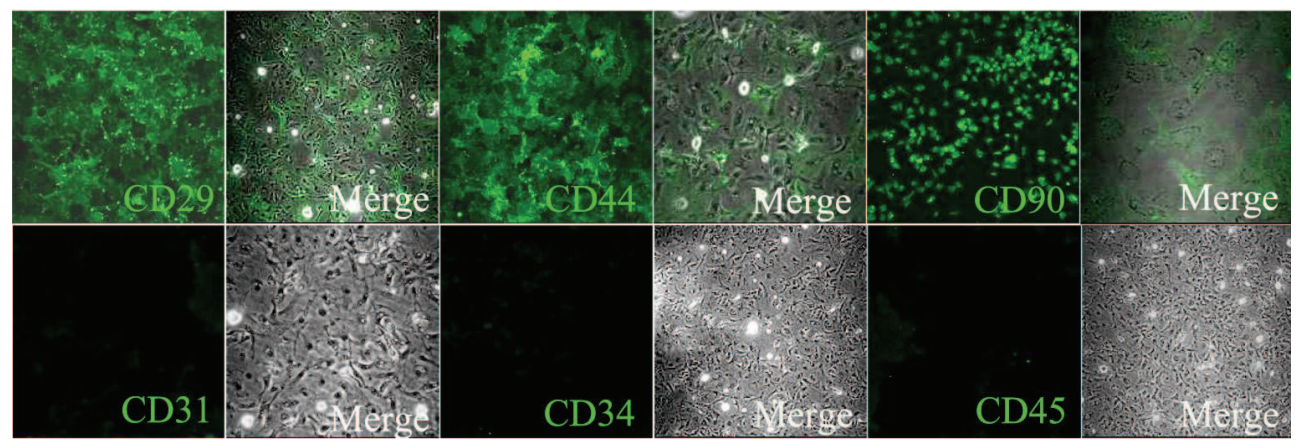

Fig. 6. Surface marker expression of chicken bone marrow MSCs of passage $5(100 \times)$. Chicken bone marrow MSCs express numerous surface markers including CD29, CD44 and CD90, but no hematopietic markers such as CD31, CD34 and CD45. 


\subsubsection{Stem cell characteristics}

Both the characteristic markers and the ability of multi-lineage differentiation are detected in this section, which are indicative of stem cell nature.

\section{Identification of characteristic markers}

The specific surface markers of stem cells were detected via immunofluorescence and RTPCR assay. The results of immunofluorescence staining and RT-PCR assay are as shown in Figs. 6- 9.

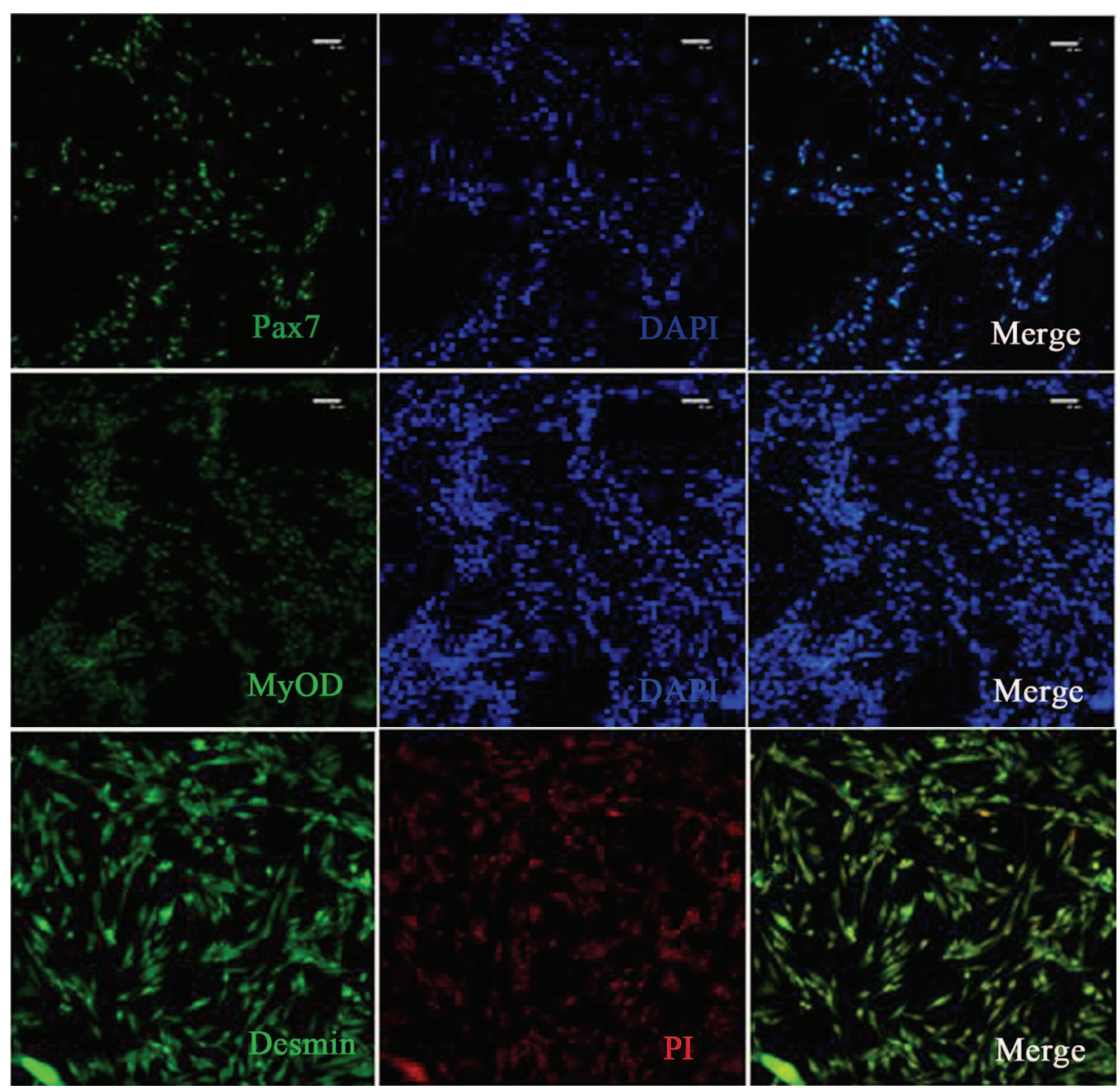

Fig. 7. Identification of chicken skeletal muscle satellite cells. Chicken skeletal muscle satellite cells express Pax7 and MyoD in nucleus, and Desmin in cytoplasm (100×). 


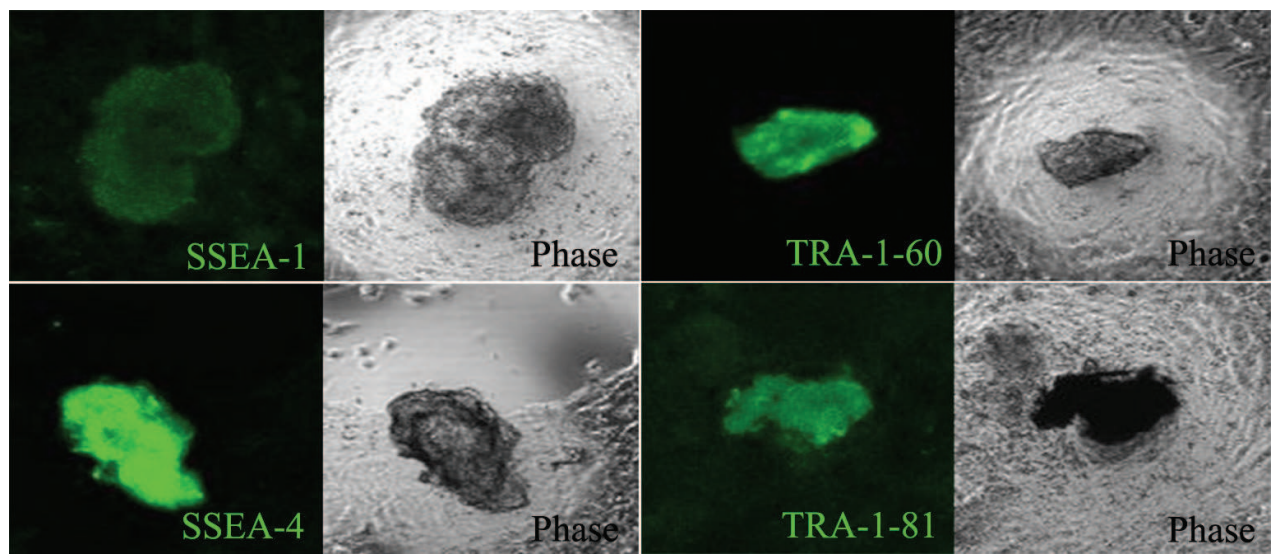

Fig. 8. Identification of colony formation in chicken PGCs of passage 3 with a set of antibodies recognizing specific cell surface antigens. Chicken PGCs express SSEA-1, SSEA-4, TRA-1-60 and TRA-1-81.

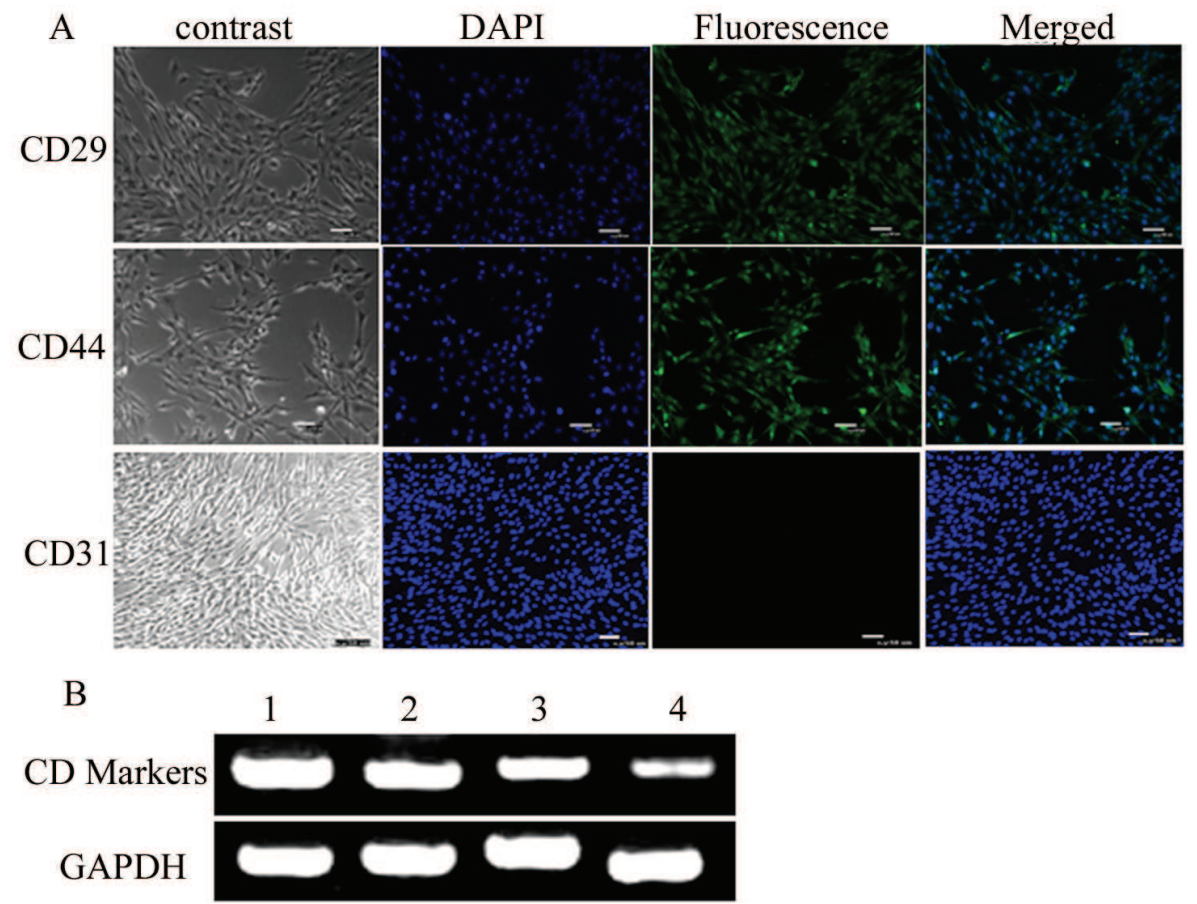

Fig. 9. Surface markers of chicken ADSCs. (a) Immunofluorescence showed that CD29 and CD44 are positively expressed, while CD31 detection is negative. Scale bars $=50 \mu \mathrm{m}$. (b) RTPCR analysis shows that the ADSCs express CD29, CD44, CD71 and CD73. In Panel (b), the lanes are in accordance to CD29, CD44, CD71 and CD73 from left to right. GAPDH in the lower picture serves as internal control. 

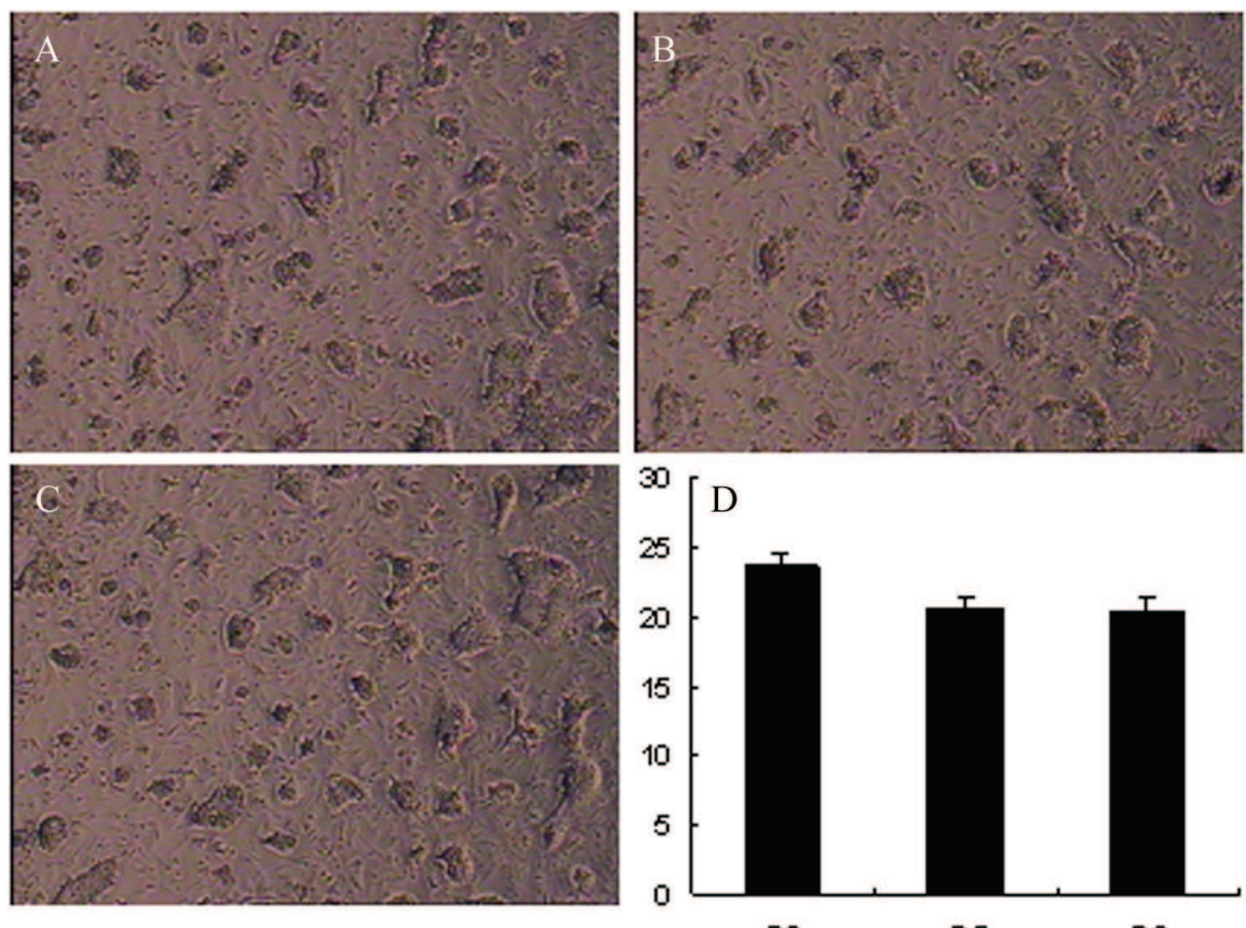

P3

P5

$\mathrm{Pg}$

Fig. 10. Colony-forming assay. Colony-forming units of P3, P5 and P9 ADSCs were counted, which indicated that colony-forming rates decreased but didn't disappear with increasing passage number. (A), (B) and (C) are colonies of P3, P5 and P9 respectively, (D) is the bar chart of colony-forming rates for chicken ADSCs of different passages.

\section{Clonogenic assay}

The self-renewal of the stem cells was evaluated via clonogenic assay. Colony formation was observed 4 days after plating under the microscope. The colony-forming rates of chicken ADSCs were $23.61 \pm 0.14 \%, 20.54 \pm 0.31 \%, 20.37 \pm 0.46 \%$ for passages 3,5 and 9 respectively, demonstrating their self-renewal ability (Fig. 10).

\section{Differentiation detection}

The multi-potency of stem cells is one of the most important prerequisites for autologous cell therapy. Therefore, different types of stem cells, e.g. bone marrow MSCs, ADSCs, PGCs, etc., were subjected to induced differentiation to assess the multi-lineage potentials.

\section{Osteogenic differentiation}

After incubation in osteogenic medium for about 15 days, morphological changes of the stem cells were obviously observed. The cells changed to tri-dimensional firstly, and then aggregated and formed mineralized nodules with increasing incubation time. Furthermore, the nodules were identified calcium positive. (Figs. 11-12) 


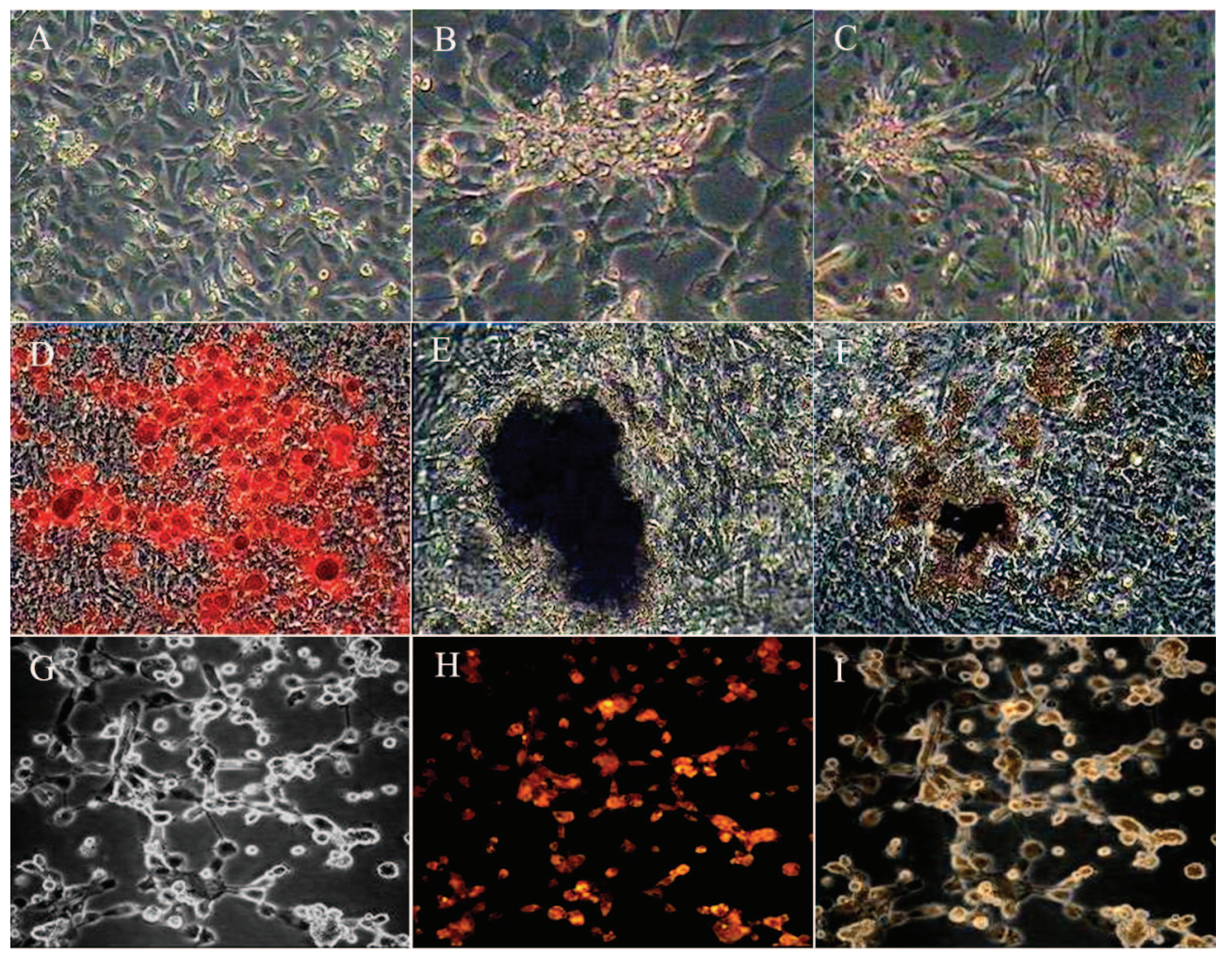

Fig. 11. Identification of osteogenic differentiation of chicken bone marrow MSCs of passage 5. (A) induction group at day $6(100 \times)$; (B) osteogenesis at day $9(100 \times)$; (C) osteogenesis at day 14; (D) alizarin red staining (100x) and (E) AKP identification with the Gomori Ca-Co's method two weeks after osteogenic induction (100×); (F) Von Kossa staining positive four weeks after osteogenic induction, indicative of calcium deposition $(100 \times)$; $(\mathrm{G})$ phase, $(\mathrm{H})$ fluorescence, and (I) merge of tetracycline labelling at day 21 post osteogenic induction. 
A
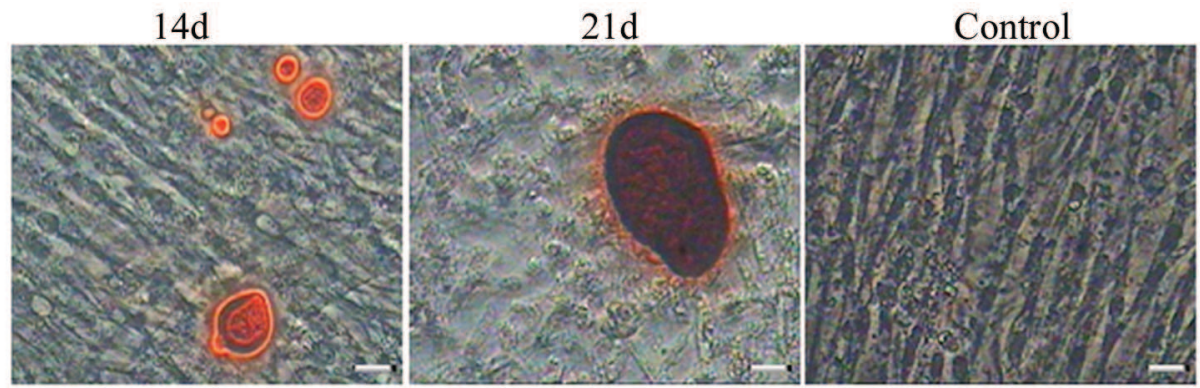

$\mathrm{B}$

1

2

3

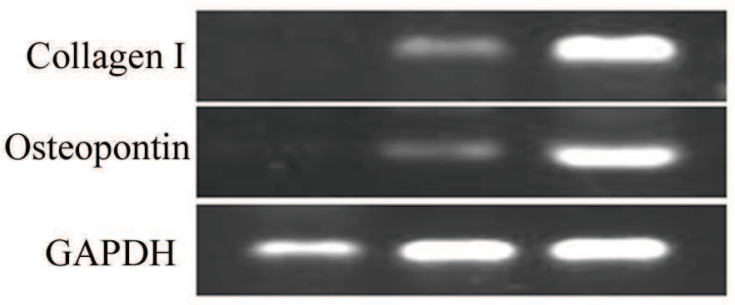

Fig. 12. Osteogenic differentiation of chicken ADSCs. (a) After incubation in osteogenic medium for 14 days, the cells metamorphosed from fusiform to tridimensional shapes, and Alizarin Red staining was positive. The nodules became more and larger with prolonged inducing time. About 21 days later, the nodules were obviously observed following Alizarin Red staining. Cells cultured in complete medium were not influenced in morphology or stained by Alizarin Red. Scale bars $=25 \mu \mathrm{m}$. (b) RT-PCR assay revealed the expression of osteoblast specific genes, including collage type I and osteopontin in the induced group after incubation for 14 days (Lane 2) and for 21 days (Lane 3); while these genes were not expressed in control (Lane 1). 


\section{Adipogenic differentiation}

Adipogenic differentiation of the stem cells can be evidenced by positive Oil Red O staining (Jing et al., 2007). After incubation in adipogenic medium for 3 weeks, the stem cells changed their morphology, and there were many lipid droplets in the cells. The number of droplets increased in a time dependent manner and tiny lipid droplets aggregated to form larger ones. In the control, cells cultured in complete medium all through the culture process were not stained by Oil Red O (Figs. 13-14).

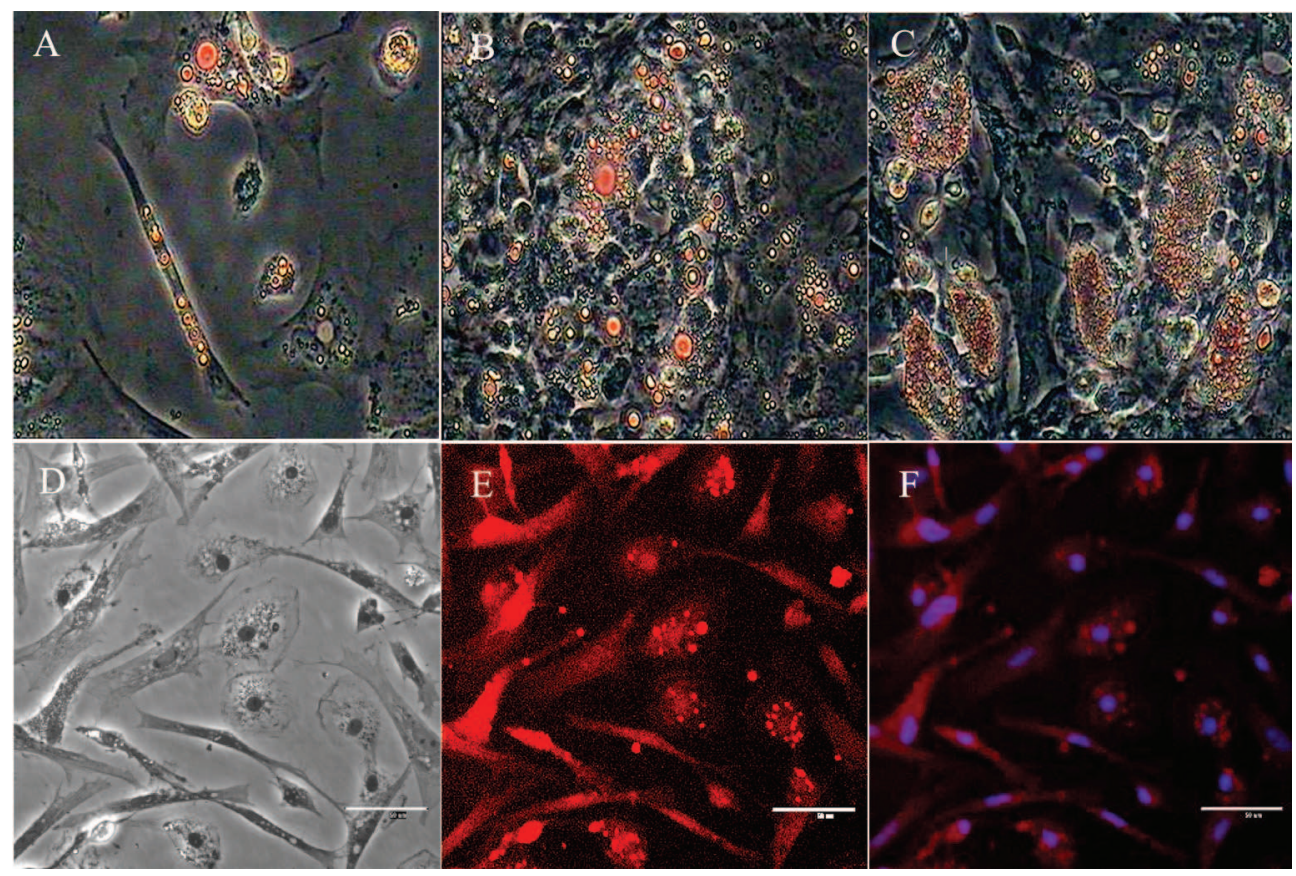

Fig. 13. Oil red-O staining and immunofluorescence of chicken bone marrow MSCs after adipogenic induction. Cells stained with Oil red-O post induction at (A) day 5; (B) day 7; and $(\mathrm{C})$ day 21; the induced chicken bone marrow MSCs are FABP positive as revealed by immunofluorescence; (D) phase; $(\mathrm{E}) \mathrm{FABP}+(\mathrm{F})$ merge of FABP and DAPI. 
A $21 d$ $28 \mathrm{~d}$ control
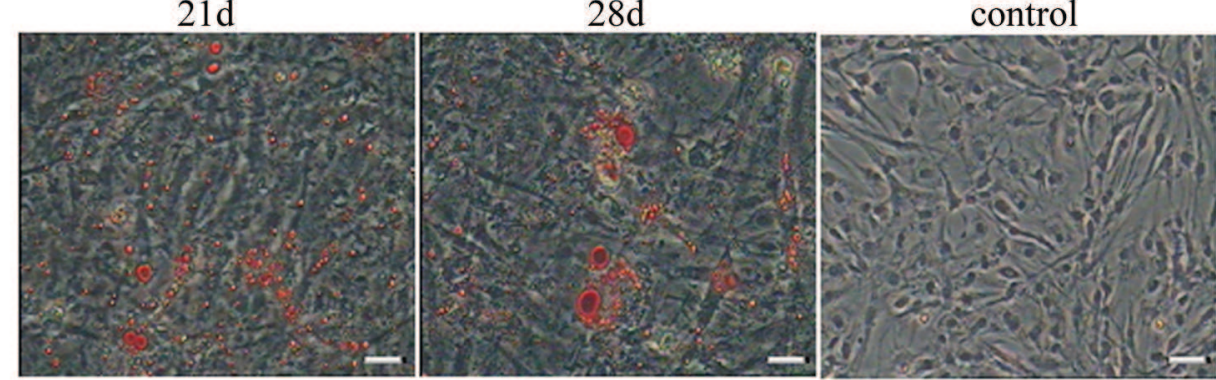

B

2 3

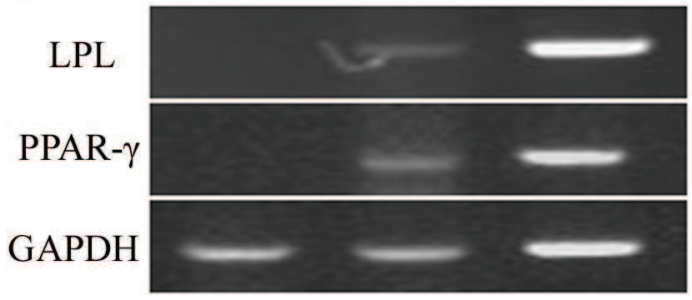

Fig. 14. Adipogenic differentiation of the ADSCs. (a) After 3-week induction, ADSCs metamorphosed from fibroblast-like to oblate and formed many lipid droplets in cells. Along with the prolongation of inducing time, droplets increased and aggregated to form larger ones gradually. As for negative control, cells cultured in complete medium all through the culture process didn't change in morphology and wasn't stained by Oil Red O. Scale bars $=25 \mu \mathrm{m}$. (b) the expression of adipocyte specific genes, including LPL and PPAR- $\gamma$, were detected using RT-PCR assay in induced group at day 21 (Lane 2) and day 28 (Lane 3), while these genes were not expressed in control (Lane 1).
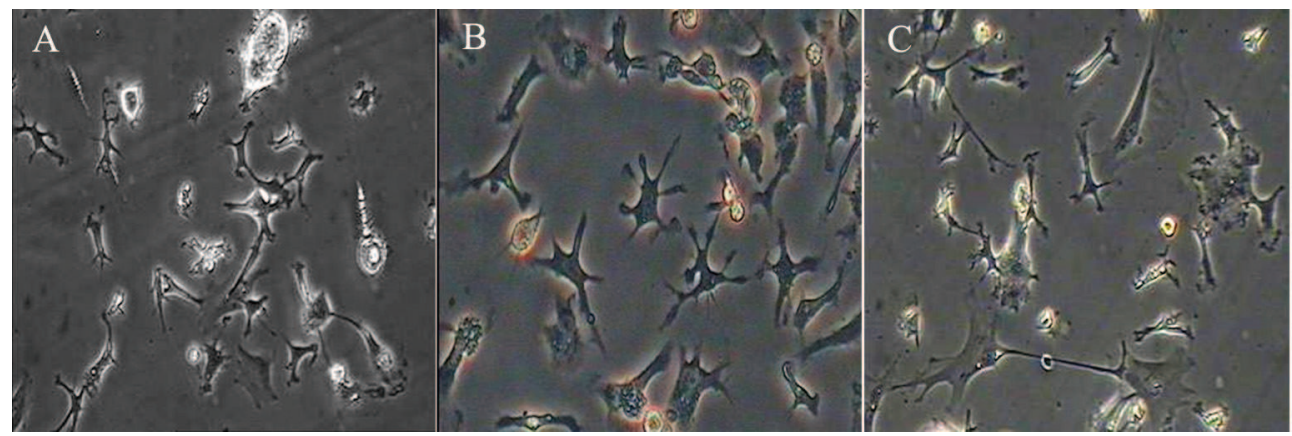

Fig. 15. Neural differentiation of chicken bone marrow MSCs (100x) treated for (A) $1 \mathrm{~h}$; (B) 3 $\mathrm{h}$; and (C) $5 \mathrm{~h}$. 


\section{Neurogenic differentiation}

Once the induction began, cell bodies of chicken bone marrow MSCs further contracted and became round, triangular or cone-shaped with multi-polar processes. Processes continued to ramify, displaying many branches, and growing cone-like dendrites. Some cells underwent a long process with evident varicosities, similar to the long axon of Golgi I neuron (Fig. 15). The expression of neural markers including Nestin, NSE and GFAP then became positive (Fig. 16).

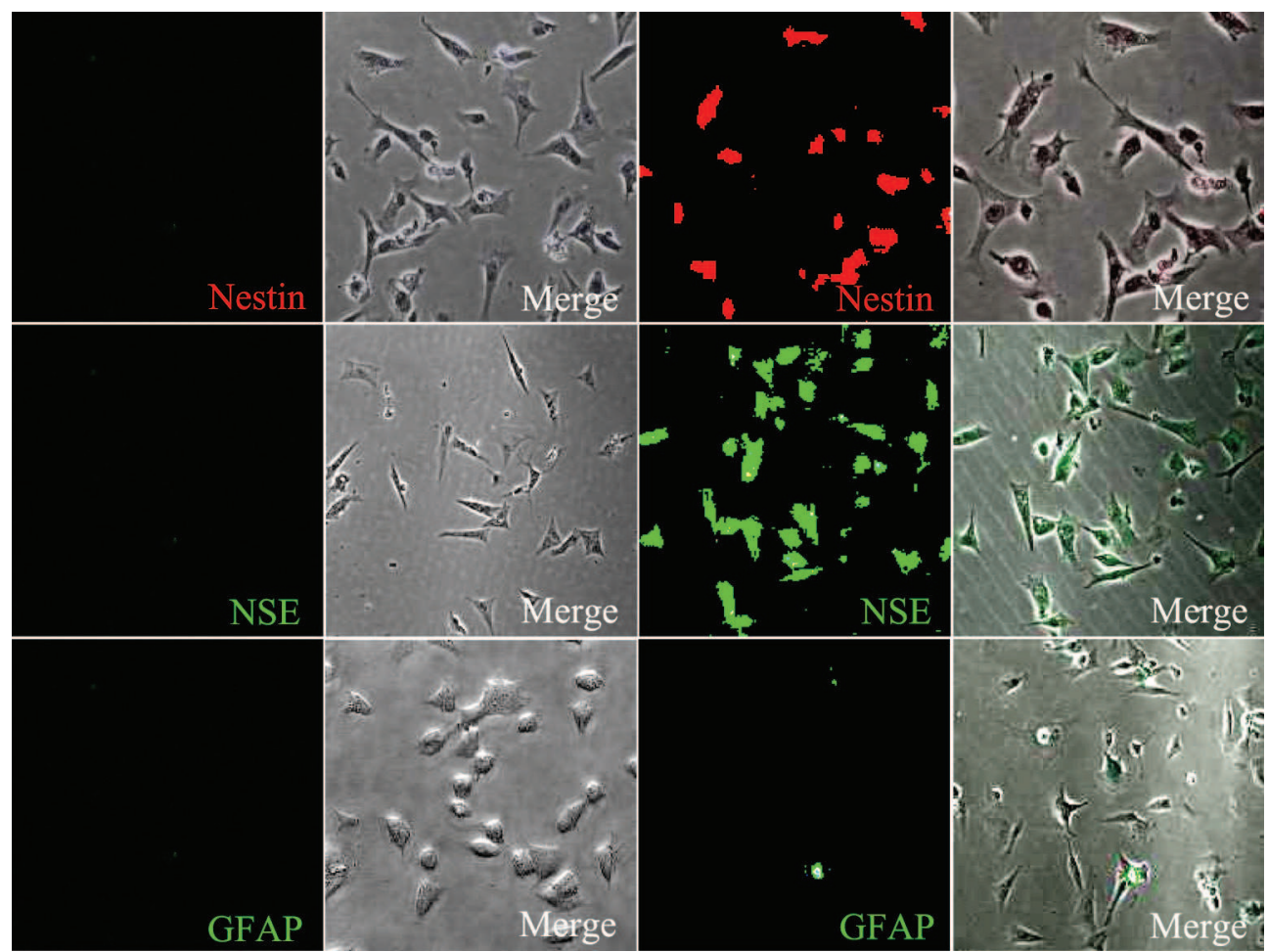

Fig. 16. Immunofluorescence detection of Nestin, NSE and GFAP expression in chicken bone marrow MSCs of passage 3 post $6 \mathrm{~h}$ neurogenic induction. 


\section{Cardiomyogenic differentiation}

After incubation in cardiomyogenic medium, the cells polymerized to form myotubules, and the myotubules increased and fused to form fascicle as time passed by. Autopulse of the myotubes was observed after about 21 days. There were no obvious morphological changes in the control group (Fig. 17).

A

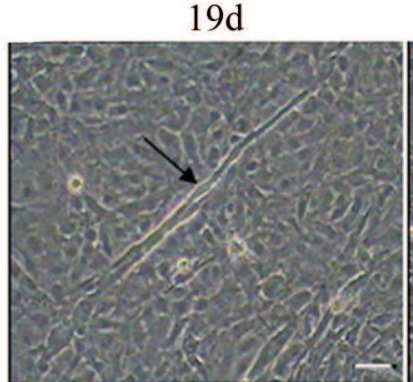

$28 \mathrm{~d}$

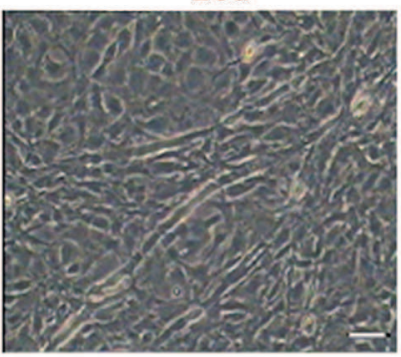

Control

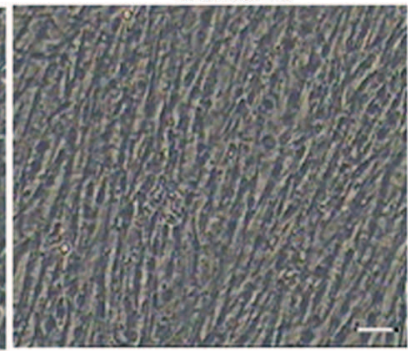

B 1 2

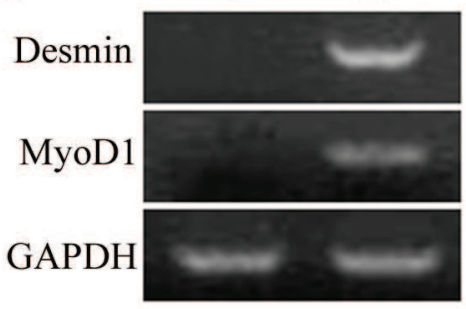

Fig. 17. Cardiomyogenic differentiation of chicken ADSCs. (A) The cells polymerized to form myotubules after culture in cardiomyogenic medium for 19 days (arrow). Around day 28 , the myotubules increased and fused to form fascicles. There was no obvious metamorphosis in control. Scale bar=50 $\mu \mathrm{m}$. (B) Myocyte specific genes, Desmin and MyoD1, were detected via RT-PCR assay after incubation in cardiomyogenic medium for 28 days (Lane 2), while these genes were not detected in control (Lane 1).

\section{Conclusion}

Animal genetic resources are encountering a challenging moment, for which reason scientists are making every effort to store the genetic materials in a long term, so that they can be explored completely and appropriately, however valuable they may seem from current point of view.

Researchers have been making every effort to preserve and to exploit animal genetic resources. At present, preservation in terms of individual animals, semen, embryos, genomic libraries and cDNA libraries are all alternative methods. However, myriads of practical problems exist on the following grounds: i) endangered species and breeds are incredibly diversified, making it unlikely for individual preservation; ii) some key techniques remain flawed, ruling out semen and embryos as an option; iii) confined by limited self-proliferation potential, mere genome DNA or organ preservation is insufficient 
for long term utilization; iv) despite of the proliferative properties of genomic libraries and cDNA libraries, they are not the basic unit of life activities, moreover, their cellular function can only be embodied by transgenic techniques.

Stem cells, due to their self-renewal ability and multi-lineage differentiation potentiality, have attracted extensive attention in medicine and biological sciences. Preservation of stem cells not only inherits the merits of somatic cell preservation, but also obtains extra advantages owing to their intrinsic characteristics.

It's worth mentioning that stem cells are far from being thoroughly investigated, especially for the ex vivo culture system. The development relies very much on daring and creative attempt, as well as repetitive testing. Fortunately, in Animal Population Culture Collection of China (APCCC), a series of stem cell lines from animal embryos and adults, such as primordial germ cells, bone marrow mesenchymal stem cells, neural stem cells, cardiac progenitor cells, endothelium progenitor cells, adipose stem cells and umbilical cord mesenchymal stem cells have been established and cyropreserved, which serve for the preservation of animal genetic resources after identification for their biological characteristics and multi-lineage differentiation potentials. Comprehensive assays, including morphology, microbial contamination, isozyme testing, karyotype, growth dynamics and surface antigen detection, are performed. After serial passage cell growth curves still display typical "S" types; microbial tests are all negative; isozyme patterns maintain specificity; and cells possess sound chromosome genetic stability. Exogenous genes are introduced into stem cells and get stable expression, testifying the cell lines have good performance at gene expression level. The identification results show that the established stem cell lines have stable and normal biological properties, meeting all the cell line quality control standards enacted by American Type Culture Collection (ATCC). Furthermore, the preserved cells retain good stem characteristics. Molecular markers are detected for the proof of their identity. Multi-germ-layer differentiation potential are tested, including the differentiation to ectoderm cells represented by neural cells, to mesoderm cells, e.g. the osteoblasts, adipocytes and cardiac muscle cells, and to endoderm cells, mainly epithelial cells.

In this sense, the APCCC has established a set of technical system suitable for the preservation of animal genetic resources in terms of stem cells, which is promising in generalizing to all kinds of animal species, therefore effectively protecting genetic treasures shaped in millions of years.

\section{Acknowledgment}

This research was supported by the "863" National Major Research Program (2006AA10Z198, 2007AA10Z170), National Key Technology R\&D Program (2006BAD13B08) and National Scientific Foundation of China (30671539).

\section{Abbreviations}

ADSCs Adipose derived stem cells

AKP Alkaline phosphatase

APCCC Animal Population Culture Collection of China

ATCC American Type Culture Collection

ESCs Embryonic stem cells

ASCs Adult stem cells 
MSCs Mesenchymal stem cells

NSCs Neural stem cells

NSPCs Neural stem and progenitor cells

PDT Population doubling time

PGCs Primordial germ cells

SCs Satellite cells

\section{References}

Bai C.Y., Li C.Y., Jin D.P., Guo Y., Guan W.J., Ma Y.H. \& Zhao Q.J. (2010). Establishment and characterization of a fibroblast line from Landrace. Artif Cell Blood Sub, Vol. 38. No. 3. Pp. (129-135).

Doyle A., Hay R., Kirsop. \& B.E., (1990). Animal cells, living resources for biotechnology. Cambridge University Press, pp(81-100). Cambridge, U.K.

Ford C. E., Pollock D. L. \& Gustavsson I. (1980). Proceedings of the First International Conference for the Standardization of Banded Karyotypes of Domestic Animals. Hereditas. Vol. 92. No. 1. pp. (145-162).

Freshney R.I., 2000. Culture of animal cells: A manual of basic technique. 4th ed. Wiley-Liss, Hoboken, NJ. Pp. (149-175). ISBN: 9780471453291. New York.

Hay, R. I., (1992). Cell line preservation and characterization. Animal cell culture: a practical approach. 2nd edn (Ed. R. I. Freshney). Oxford University Press, pp. (104-135). Oxford.

Heim R, Cubitt AB \& Tsien RY. (1995). Improved green fluorescence. Nature, Vol. 373. No. 6516. pp. (663-664).

Jing W., Lin Y., Wu L., Li X., Nie X., Liu L., Tang W., Zheng X. \& Tian W., (2007). Ectopic adipogenesis of preconditioned adipose-derived stromal cells in an alginate system. Cell Tissue Res, Vol. 330. No. 3. pp. (567-572).

Li L.F., Bai X.J., Gong X.L., Liu H.K., Chen L.N., Guan W.J. \& Ma Y.H. (2009). Differentiation potential of bone marrow mesenchymal stem cells in duck. J Genet Genomics, Vol. 36. No. 3. Pp. (133-140).

Liu C.S., Wang Z.G. \& Li N. (2004). Status and strategy of protection of endangered animal genetic resourse in China. China Animal Husbandry Bulletin, Vol. 21, No. 017, pp. (28-31).

Ma Y.H. \& Wu C.X. (2001). Evaluation of Threatening Degree of the Animal Genetic Resources in China. Acta Ecologae Animalis Domastici, Vol. 22, No. 2, pp. (8-13).

Masover G. K. \& Becker, F. A., (1998). Detection of mycoplasmas in cell cultures by cultural methods. Methods in molecular biology. Vol. 104: Mycoplasma protocols. Humana Press nc. pp. 207-15, 217-26. Totawa NJ.

Qu Z., Balkir L., Van Deutekom J.C., Robbins P.D., Pruchnic R. \& Huard J. (1998). Development of approaches to improve cell survival in myoblast transfer therapy. J Cell Biol, Vol. 142, No. 5, pp.(1257-1267).

Ren ,F. L., Li ,Y., Zhang, Y., (2002). In vitro cultivation and freezing of bovine skin fibroblast cells. Scalper Magazine. Vol. 28. pp. (8-10).

Tsuchiya R, Yoshiki F, Kudo Y, Morita M.l (2002). Cell type-selective expression of green fluorescent protein and the calcium indicating protein, yellow cameleon, in rat cortical primary cultures. Brain Research. Vol. 956. No. 2. pp. (221-229).

Zhang L. (2003). Animal Breeding, China Radio \& TV University Press. BeiJing. 


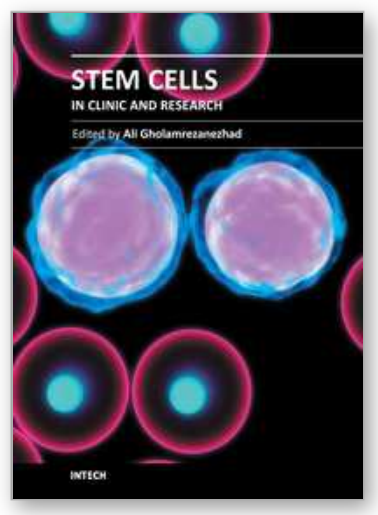

\author{
Stem Cells in Clinic and Research \\ Edited by Dr. Ali Gholamrezanezhad
}

ISBN 978-953-307-797-0

Hard cover, 804 pages

Publisher InTech

Published online 23, August, 2011

Published in print edition August, 2011

Based on our current understanding of cell biology and strong supporting evidence from previous experiences, different types of human stem cell populations are capable of undergoing differentiation or trans-differentiation into functionally and biologically active cells for use in therapeutic purposes. So far, progress regarding the use of both in vitro and in vivo regenerative medicine models already offers hope for the application of different types of stem cells as a powerful new therapeutic option to treat different diseases that were previously considered to be untreatable. Remarkable achievements in cell biology resulting in the isolation and characterization of various stem cells and progenitor cells has increased the expectation for the development of a new approach to the treatment of genetic and developmental human diseases. Due to the fact that currently stem cells and umbilical cord banks are so strictly defined and available, it seems that this mission is investigationally more practical than in the past. On the other hand, studies performed on stem cells, targeting their conversion into functionally mature tissue, are not necessarily seeking to result in the clinical application of the differentiated cells; In fact, still one of the important goals of these studies is to get acquainted with the natural process of development of mature cells from their immature progenitors during the embryonic period onwards, which can produce valuable results as knowledge of the developmental processes during embryogenesis. For example, the cellular and molecular mechanisms leading to mature and adult cells developmental abnormalities are relatively unknown. This lack of understanding stems from the lack of a good model system to study cell development and differentiation. Hence, the knowledge reached through these studies can prove to be a breakthrough in preventing developmental disorders. Meanwhile, many researchers conduct these studies to understand the molecular and cellular basis of cancer development. The fact that cancer is one of the leading causes of death throughout the world, highlights the importance of these researches in the fields of biology and medicine.

\title{
How to reference
}

In order to correctly reference this scholarly work, feel free to copy and paste the following:

Weijun Guan, Xiangchen Li, Dapeng Jin, Xiaohong He, Yabin Pu, Qianjun Zhao, Taofeng Lu, Chunyu Bai, Shen Wu, Xiaohua Su and Yuehui Ma (2011). Stem Cell Culture Collection - Promising Strategy for Animal Genetic Resource Preservation, Stem Cells in Clinic and Research, Dr. Ali Gholamrezanezhad (Ed.), ISBN: 978-953-307-797-0, InTech, Available from: http://www.intechopen.com/books/stem-cells-in-clinic-andresearch/stem-cell-culture-collection-promising-strategy-for-animal-genetic-resource-preservation

\section{INTECH}

open science | open minds 


\section{InTech Europe}

University Campus STeP Ri

Slavka Krautzeka 83/A

51000 Rijeka, Croatia

Phone: +385 (51) 770447

Fax: +385 (51) 686166

www.intechopen.com

\section{InTech China}

Unit 405, Office Block, Hotel Equatorial Shanghai No.65, Yan An Road (West), Shanghai, 200040, China

中国上海市延安西路65号上海国际贵都大饭店办公楼 405 单元 Phone: +86-21-62489820

Fax: +86-21-62489821 
(C) 2011 The Author(s). Licensee IntechOpen. This chapter is distributed under the terms of the Creative Commons Attribution-NonCommercialShareAlike-3.0 License, which permits use, distribution and reproduction for non-commercial purposes, provided the original is properly cited and derivative works building on this content are distributed under the same license. 